\title{
Beyond What We Seeing: An Inter Site Spatial Pattern of Megalithic Burial Complexes in Yan Oya Middle Basin (YOMB), Sri Lanka
}

\author{
Mangala Katugampola
}

\begin{abstract}
Though the classical archeological approach based on interpretation of archeological data such as structures, artifacts, and features has a long history, it is regarded as a singular approach for research. Amidst this context, this study tries to extend the methodological approach based on the Post-processual archeology which tries to understand the collective behavior of all above facts which gives an overall picture of the scenario. A burial considered as a land mark of an individual or of a society, exposes the historical information in its material sense while it could also be explained in its visual meaning. The burial complexes spread all over the Yan Oya basin becomes significant subjects to study the social contexts they were belongs to in the above sense. The objective of present study is to relate spatial distribution patterns of burials with their materials and architectural features, instead studying mire structures. Accordingly, the study strives to explain the depositional behavior of a burial through the principles of spatial archeology which enable to expose the socio-environmental contexts of the based communities.
\end{abstract}

Index Terms-Megalithic burials, spatial analysis, cultural landscape, deathscape, Yan Oya Middle Basin (YOMB), Sri Lanka.

\section{INTRODUCTION}

The place where a person is cremated after death or a burial could be considered as a reflection of the respective person as well as the society itself. From world renowned Tutankhamen burial of Egypt to burials of the modern society could be illustrated for this. Leading the life of an individual is of significance and equally leaving from the life too important. Mortuary practice essentially a cultural practice concerning the transition from life to death [1].

Historically, a burial has been a special monument of commemoration. Material evidences recorded from such monuments explicate both the individual person as well as the society he lived in. Creation of such tombs serves several objectives including, commemoration, respect as well as the dominion of land depending on the definitions of various social contexts. An illustration for this is evident from throughout the world. Megalith culture is one of the classic examples for the above. "Megalith" was originally used to designate any ancient architecture composed of large multi-ton stone. This would include single standing

Manuscript received August 7, 2015; revised October 19, 2015.

Mangala Katugampola is with University of Kelaniya, Sri Lanka (e-mail: mkatugampola@yahoo.com252). stones, certain tombs and stone circles.

This megalithic tradition originated in Western Europe was gradually popular around the world. Scholars have various thoughts on this through hundred years of debates. Glyn Daniel (1959) argued that megalithic tombs and temples are not the same around the world and that the use of large stones in different parts of the world in architecture that had little else in common might well have arisen independently and was not likely wondering Egyptians. "there is no necessary cultural or chronological or functional link between all megalithic monuments" [2]. Another group of scholars argues that megalithic monuments are of social centers and they further claims that these monuments have been used to demarcate territorial boundaries.

Megalithic tombs often function as territorial makers in segment societies [3], [4]. Though this is a controversial claim, it underpins the separation of territories in diversely segmented societies settled closer to each other. Renfrew identify this as territoriality. Even though this is of Western European origin the reflective meaning of this has provided the fundamental issue for the present study or in other words the spatial distribution of such monuments.

A burial exposes the historical information in its material sense while it could also be explained in its visual meaning. Various examples for this could be mentioned from different regions of the world. Burial could be considered as a land mark of an individual or of a society. In another sense it's a visual expression of social behavior of a certain time period.

The burial complex spread all over the Yan Oya basin becomes significant subjects to study the social contexts they were belongs to in the above sense. The objective of present study is to relate spatial distribution patterns of burials with their materials and architectural features, instead studying mire structures.

Accordingly, the study strives to explain the depositional behavior of a burial through the application of spatial archeology principles.

\section{Region-YAN OYA MiddLe BASIN}

The area between Hurulu väva and Horowpotana may be called the middle basin of the Yan Oya (Fig. 1). This is the area which is the centre of focus on this study. Eastern highway that once connected the ancient Anuradhapura with the Gokannatittha harbor stretched across the area. In the area of Kok -ebe , the Yan Oya divide in to two whereas it connects up again as a single river in Horowpotana. The 
total area of the middle basin is $1996 \mathrm{~km}^{2}$. The area consists of vegetation of the dry zone as well as several scattered hills.

According to the archaeological evidence the area is belonging to proto historic period (1300-400 BC). In this study main focus is on the mortuary remains belonging in the proto-historic period and specifically on the megalithic burials of this period and their positioning in the archaeological landscape of the Yan Oya river basin of the North Central Province of Sri Lanka. At present the Yan Oya river basin considered to be an archaeological landscape with highest number of megalithic burial sites located in the North Central dry zone.

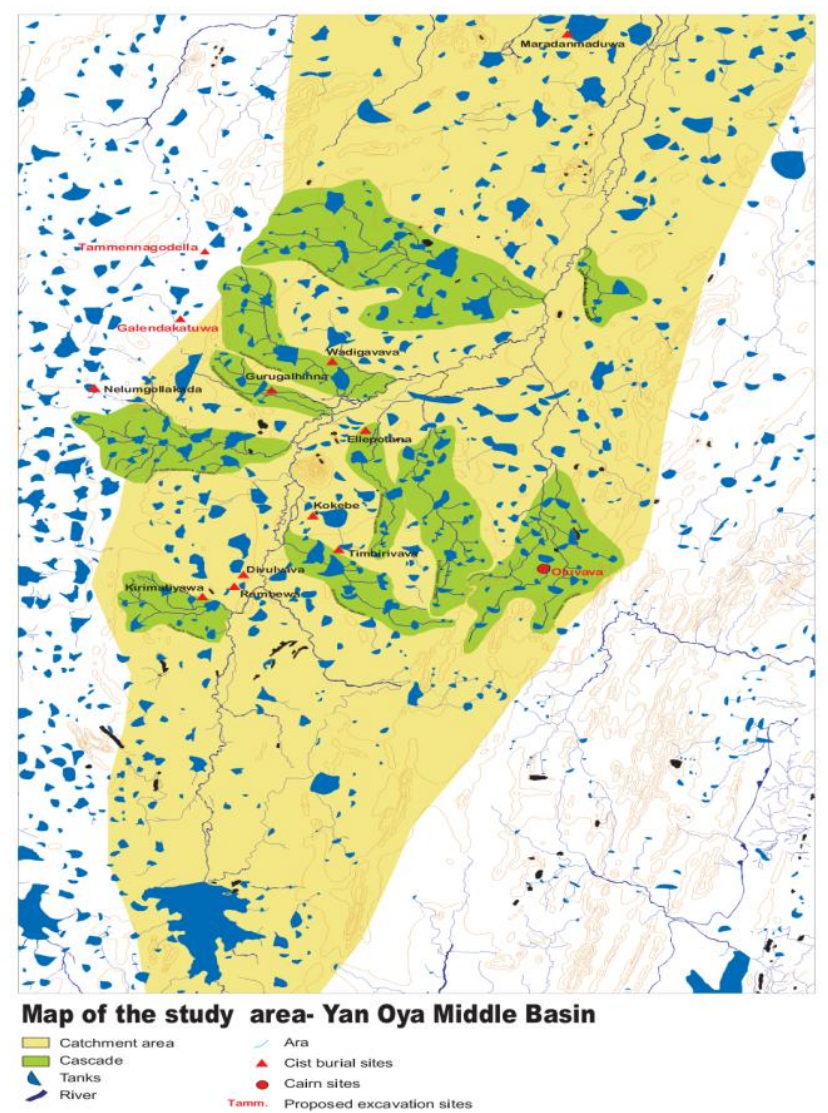

Fig. 1. Study area.

The Sri Lankan Proto and Early historic mortuary remains are significant for its distinct material records known as the megalithic burial tradition. Presently, more than 50 burial complexes have been revealed from all most all the atmospheric zones of Sri Lanka and it is known as the cultural identity of that era or 'megalithic culture'. Scientific time verifications and results show that culture belonging between $1300 \mathrm{BC}$ and $200 \mathrm{AD}$ [5].

The diversity in cemetery types argues for the existence of a complex mortuary tradition. It can also be suggested that this complexity is also indicative of or a reflection of the presence of different social groups. Clustering of graves, spatial distribution of burials, proximity to water, proximity to flood plain, utilization of rich soil and rock, and such situations observed in the archaeological record may be taken as supportive of this hypothesis. A behavioral understanding of this variability and the implicit patterning of the mortuary record will provide an insight into the complexity of Proto and Early historic society of Sri Lanka.
We would stress on the potential of using the mortuary remains as an analytical tool to investigate the complexity of the Proto historic society of the region. The mortuary behaviors illustrated by their spatial distribution patterns and variant patterns of ideational behavior would be elucidated by testing some spatial analytical methods in inter site level.

\section{SPATIAL RELATIONSHIP AMONG THE BURIAL}

The field survey which was undertaken of an area of 1996 $\mathrm{km}^{2}$, has covered 22 burial complexes and 92 other archeological sites. The important focus in this context was to trace, how the landscape was related with burial complexes and other archeological sites. Among the 92 other archeological sites, 19 monastery complexes, 14 ruined places, 13 settlements and 30 ancient man made tanks were recorded. Most of the artifactual data proves that ancient places mentioned above represent the proto historic period.

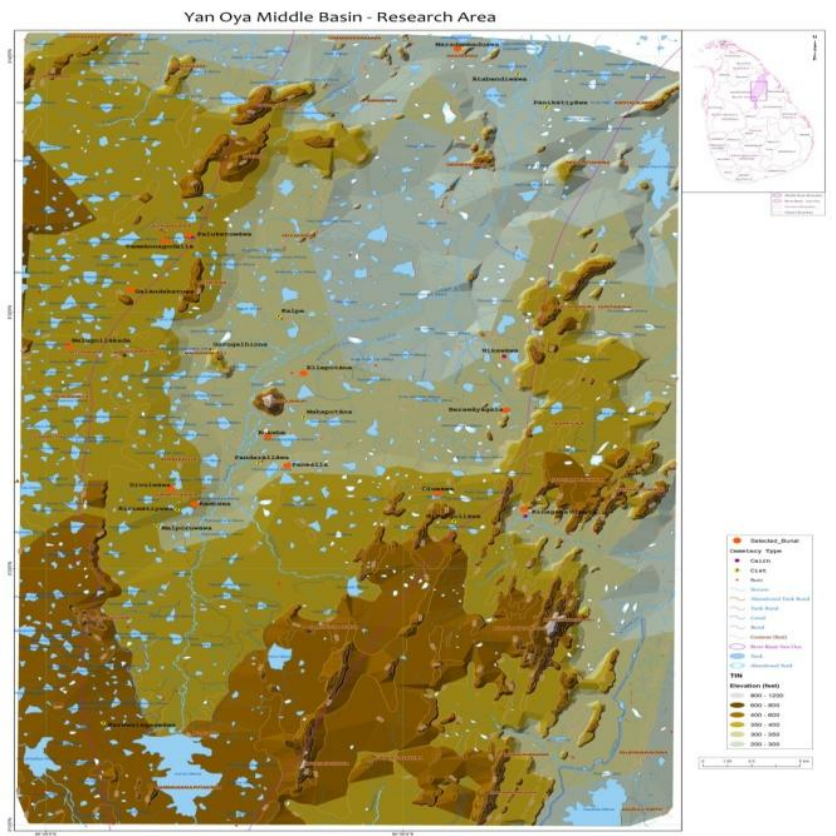

Fig. 2. Spatial distribution of the burials in the study area.

A glamorous picture can be seen when all above sites are placed on a single map. However, the logical explanation of this picture is questionable. Because, human beings individually or in groups perform their actions on natural space which results the cultural space [6]. They include the subsistence patterns and rituals of the society. Accordingly the involvement of the human beings in different environmental contexts is diverse. Similarly, the encountering of representations of different time horizons within a same time period makes complexities. All above facts can theoretically be explained by the concept of cultural diversity. The utilization pattern of the space of humans in groups or individually in the same environmental context is not precise.

The archeological sites belong to the same period were classified based on two methods. Firstly, relative dating. e.g classification of potsherds, architectural features and inscriptions. Secondly, absolute dating e.g samples from 
excavations. The archeological dispersion was examined by the post analysis. Specially, to trace the spatial relationship between the environment and the burial complexes, mapping and spatial analysis were applied.

The map gives clear idea about spatial distribution of burial sites in Yan Oya middle basin. All the burial placed on above 300 feet and lower 600 feet. If we deeply conceder about this most of the burials situated on 300-400 feet. There is no any burial situated on 200-300 feet zone. The reason is the people who lived there pat much attention for the flood.

Identification of human behavior within the Space, in other words special behaviors, is a critical factor in the discipline of archeology. Within the study are we already identified and recorded early historic places. If we consider about distance in between burial and early historic site most are surrounded by $3 \mathrm{~km}$ radius. In other hand the all the EHP (Early Historic Period) sites were located on extremely fertilized zone of the region. Basically they were selected 300-600 feet altitude range for settle. This is the most flourish land in the region for settlers. Another thing is these burials and EHP (Early Historic Period) sites can be functioning on same period, the radio carbon dating from Tammannagodella site was proved this.

\section{TANK VILlage SETTLEMENT}

The data gathered from archaeological exploration carried out in Yan oya Basin is consequence of the human activities in the past. As a whole such contexts are regarded today as spatial patterns created in separate spaces as a result of interaction of humans across time creations of individuals and communities. In modern archaeology it is described as 'human agency' [7].

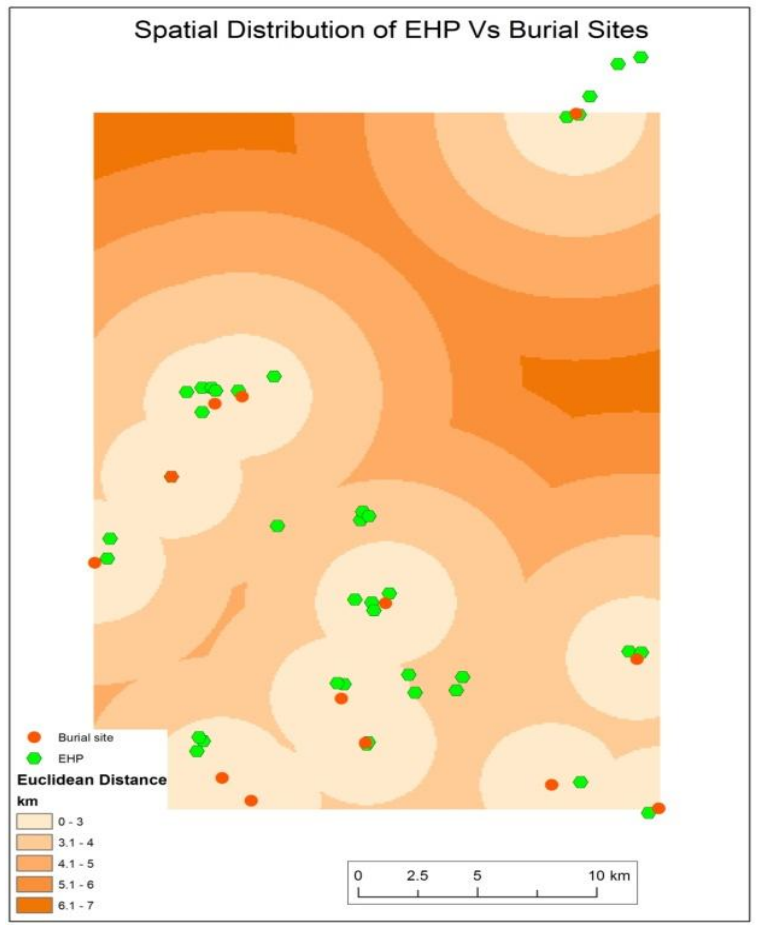

Fig. 3. Euclidean distance - Burial sites vs. early historic sites.

Archaeology use 'points' to understand archaeological entities. By classifying those points, the inter connection of the scattering of artifacts in a site or a region can be understood. Efforts were taken to understand the spread pattern of the tank villages in the research are based on spatial pattern of the region.

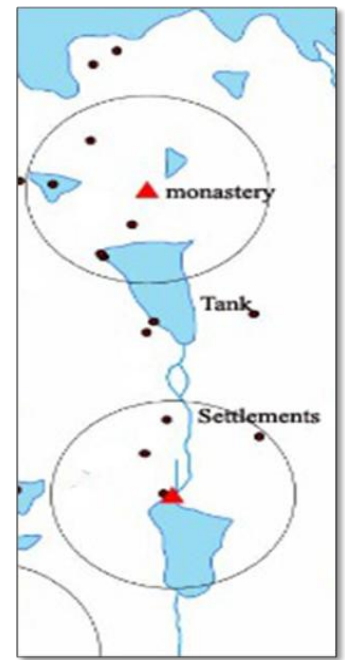

Fig. 4. Spatial pattern of the ancient tank village.

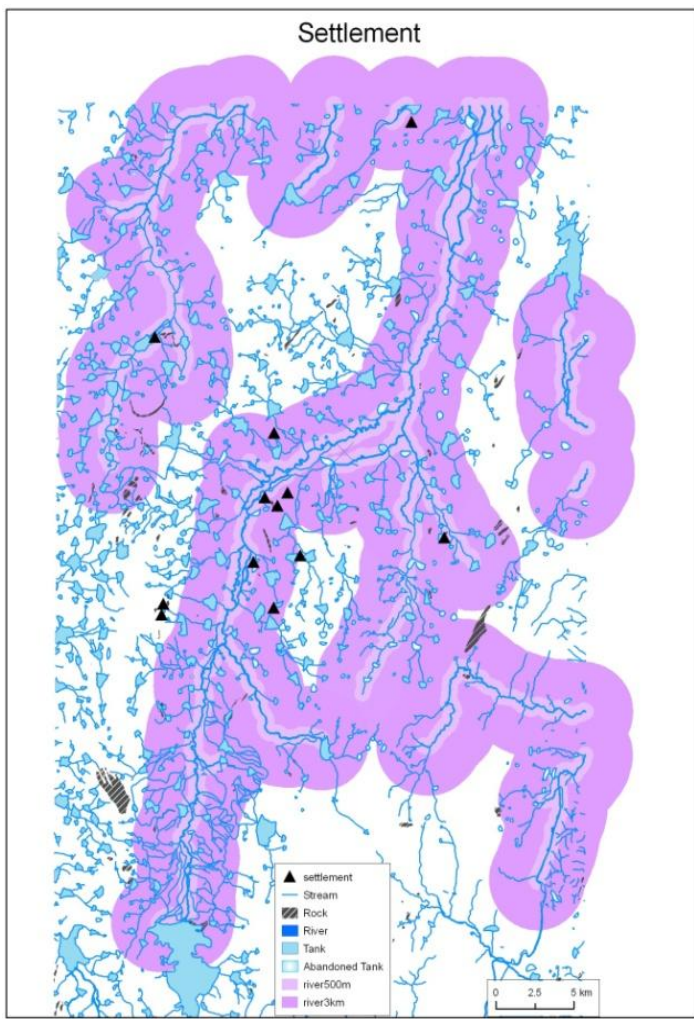

Fig. 5. Distribution of the ancient settlements of the region.

The early agricultural settlements of Sri Lanka which were established throughout the dry zone in $1^{\text {st }}$ millennium BC indicate the uniformity of their placement. [8]-[11]. The North Central plain of the Island considered as the cradle of the urbanization of the aforementioned agricultural settlements [12]. To explain further, when settlements formed placed in Sri Lanka, the natural geo landscape and the geo-physical factor very much affected the process. Especially the levee and settlement mounds are placed taking into consideration the high contours. One such model is the tank settlement system. So, evidence to show how the nature, components and model were formed is given by the traditions of sources which existed throughout a long period 
of time (Rasawahini, and Samantapasadikava) literary sources also give various evidence regarding the manner in which the ancient settlement were formed. According to the archaeological investigations we can identity general pattern of ancient village in the dry zone. The major components of the tank village system of historic period consist three main components. They are the settlement; tank and the monastery (see figure 04). The burial complex could also be placed within the above system in the study area. But the burial complex represent a different time period to the above three major components of tank settlement system. One can argue that these components are not compatible based on the different time factor. But it is a world phenomenon that the land is critical in each society. Based on the overall map which places all above components in different time periods, it could be noted that the sites are located within same radios. Correspondingly, people in different time horizons have had similarities in selecting the land.

\section{EXPLORATORY DATA ANALYSIS (EDA)}

According to Tukey (1977), "the greatest value of a picture is when it forces us to notice what we never expected to see". The conventional archeological approaches trust a great deal on what we see with our raw eye. However, visual examinations on data are being evolving in contemporary statistical techniques.

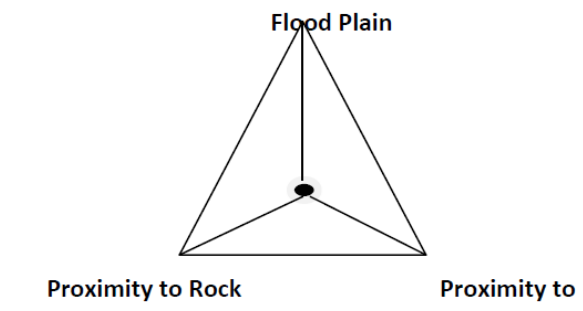

Fig. 6. Basic criteria for exploratory data analysis.

\section{A. Classification Criteria Proximity to Flood Plain}

The research site being the Yan Oya middle valley of, it basically situated in a flood plain. Most of ancient settlements in world have been located in proximity to flood plains. But, too much closer to the river bank result higher risk of being destroyed. In an archeological point of view this refers to site formation process and it has two criteria. They are Natural formation, and Cultural formation. As an archeologist this site formation process has to be considered in working in the flood susceptible areas. However, location of a settlement in proximity to a river bank itself is a risk. Therefore, any burial located within $500 \mathrm{~m}$ from the river were identified as "Near" to the flood plain. On the other hand, $500 \mathrm{~m}$ to $3000 \mathrm{~m}$ away from the river were identified as "Far" from the flood plain.

\section{B. Proximity to Water}

Establishment of a settlement has always been based on the availability of water as a resource for the settlers. Here, perennial water and man-made tanks have been considered as water resources. Within the range of $500 \mathrm{~m}$ of burial to the water resource was considered as "Near" whereas more than $500 \mathrm{~m}$ from the burial to water resource was considered as "Far" to water resource.

\section{Proximity to resource (Rock)}

Being located on a flood plain as well as due to periodical destruction over the time, very few artifacts were recorded. Mostly, rocks were found as resources in the construction of burials. Therefore, it has been considered as a resource. $2000 \mathrm{~m}$ from the burial was considered as "Near" to resource whereas more than $2000 \mathrm{~m}$ from the burial was considered as "far" to resource. Based on the above mentioned criteria, the data illustrated in further classified into four different classes as discussed below.

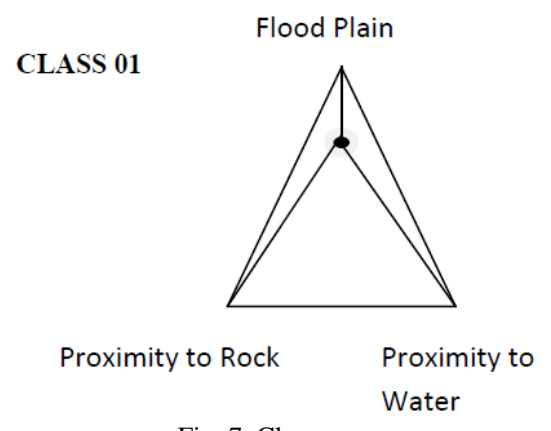

Fig. 7. Class one

The class one as illustrated in the above graph was included the burials located close flood plain and far to rock and water as classified in above number 1 criteria. Locating a burial closer to the flood plain increases the risk of destruction and being far away from the resource (rock) and water implies inefficiency. Hence, this class can be identified as the worst or most unproductive location. Most importantly, no burial was located in this class and it can be predicted that the society has had a strong sense in utilizing the environment. In an archeological point of view it can be mentioned that the settlers have been very effective in managing the space according to the above fact.

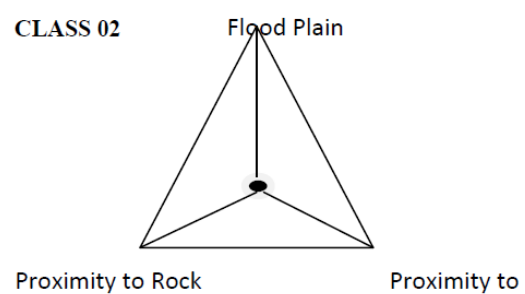

Fig. 8. Class two

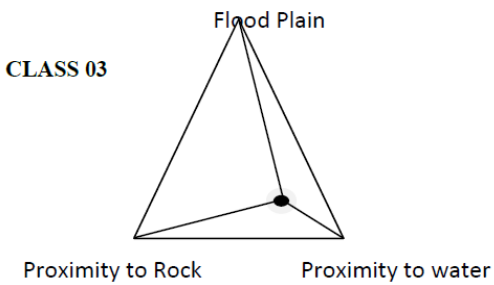

Fig. 9. Class three.

The class two as illustrated in the above graph was included the burials located far from flood plain and near to rock and water as classified in above number 1 criteria Locating a burial far from the flood plain decreases the risk of destruction and being near to the resource (rock) and water implies efficiency [13]. Hence, this class can be 
identified as the best or most productive location. Surprisingly, most of the burials were recorded under this class and it can be noticed that the location of burials has not been an accident. Further, the society has consciously managed the space in their deathscape.

The class three as illustrated in the above graph was included the burials located far from flood plain and rock and near to water as classified in above number 1 criteria. In this class the risk of destruction has been minimized by locating far from the flood plain. And also utilizing water has been efficient. But the distance to rock has been "far" due to some reasons, perhaps the lack of rocks nearby.

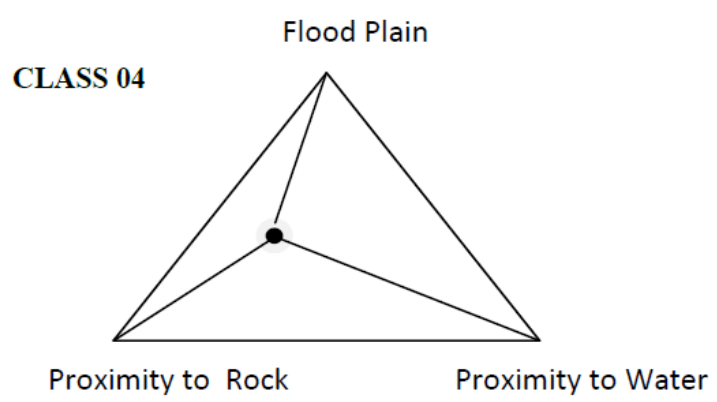

Fig. 10. Class four.

The class four as illustrated in the above graph was included the burials located near to flood plain and rock and far from water as classified in above number 1 criteria. In this class the efficiency is available only in the utilization of rock. But the distance to water has been "far" and the proximity to flood plain has been "near" making this class more inefficient in terms of risk reduction as well as water accessibility.

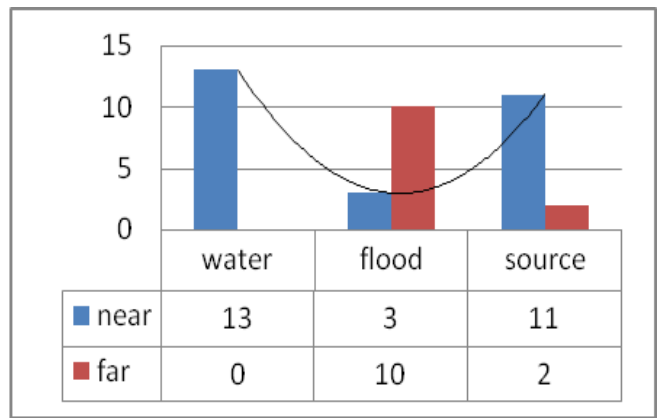

Fig. 11. Distribution of the burial complexes.

\section{Exploratory Data Analysis (EDA)}

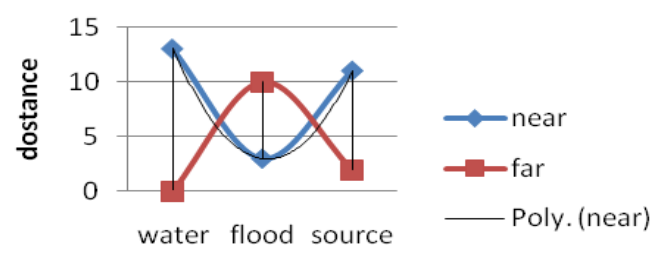

Atrribute

Fig. 12. Distribution of the burial complexes.

The above graph and the map illustrate the summery of the predictive model. Accordingly, thirteen burials were identified "near" to water and no burials were recorded "far" from water. Further, "far" from flood plain ten burials were identified whereas 3 burials were identified "near" to flood plain. Moreover, eleven burials were identified "near" to rock and two burials were recorded "far" from rock.
It is significant to note that three burials were recorded within the $500 \mathrm{~m}$ buffer zone of the flood plain. However, these three burials were not situated on main stream, identified nearby sub streams. According to the above classification, class one can be identified as the worst case while class two is the most prominent in the context of space utilization. Hence, it could be concluded that selection of the land has been sensitive in terms of natural factors[14].

In order to enhance the above illustration, a locational predictive model has been tested which is known as "Exploratory data analysis". The output of this analysis is presented in the map (Fig. 16).

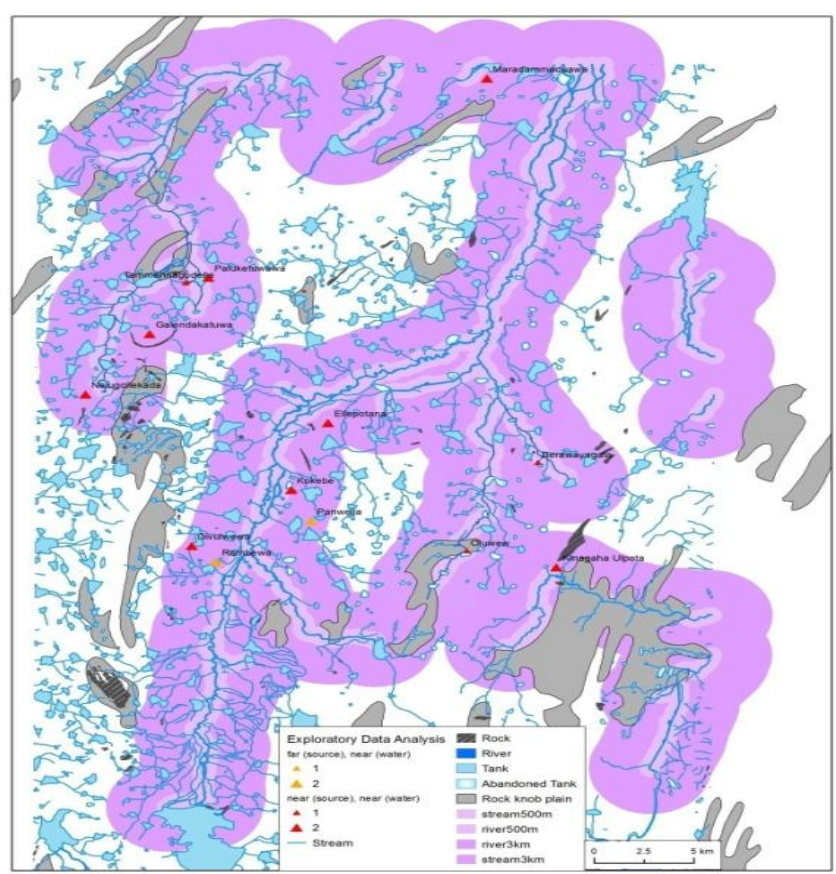

Fig. 13. Exploratory data analysis (EDA).

The large number of burials in the Yan Oya basin is the visible evidences of the ancient settlements of proto historic period in this area,[15]. How the stones were obtained to create the burials? Why all the identified burials are located near water sources? Why the material facts are visible to prove human settlements in the vicinity of burials?

These are typical problems yet to be solved to realize the nature of the ancient settlement. SCA provide clear answer for such questions. SCA assumes that the settlements were not located randomly across the landscape. But were located to maximize efficiency and minimize effort in gathering resources.

\section{CONCLUSION}

A mortuary deposit signifies a specific pattern of human activities which is far beyond the ordinary human behavior. In the course of explaining extremely complex human behaviors, the archaeology relies on the materials and the material context which have been the underpinnings of human activities. Depositional behavior has been of pivotal in reconstructing the ancient human conduct, as a significant archaeological concept. According to that this study explains the depositional behavior of a mortuary deposit using a spatial archaeological methodology and theories. 


\section{ACKNOWLEDGEMENTS}

My sincere gratitude for China Scholarship council, Postgraduate Institute of Archaeology university of Kelaniya, All team members of YOMB.

\section{REFERENCE}

[1] M. P. Pearson, The Archaeology of Death and Burial, Sutton Publishing Ltd. 2002.

[2] G. E. Daniel, A Hundred Years of Archaeology, London: Duckworth, 1950.

[3] R. W. Chapman, "The emergence of formal disposal areas and the problem of megalithic tombs in prehistoric Europe," The Archaeology of Death, Cambridge: Cambridge University Press. pp. 71-80, 1981.

[4] C. Renfrew, "Introduction: The megalith builders of Eastern Europe," Antiquity and Man: Essays in Honor of Gllyn Daniel, London: Thomas and Hudson, pp. 72-81, 1981.

[5] R. A. E. Coningham, "Anuradhapura citadel archaeological project: Preliminary report of the second season of the Sri Lankan British excavation at Salgaha Watta," June-August 1990. South Asian Studies, pp. 167-75, 1991.

[6] K. W. Butzer, Archaeology as a Human Ecology: Method and Theory for a Contextual Approach, Cambridge, Cambridge University, 1982.

[7] I. Hodder, "The meanings of things," Material Culture And Symbolic Expression, Unwin Hyman Ltd., London, 1989.

[8] S. U. Deraniyagala, "The proto and early historic radiocarbon chronology of Sri Lanka," Ancient Ceylon, vol. 12, pp. 252-92, 1990.
[9] S. D. Bandaranayake, "The settlement pattern of the proto historicearly historic interface in Sri Lanka," South Asian Archaeology, Madison: Prehistoric Press, pp. 15-23, 1992.

[10] S. Seneviratne, "The archaeology of the megalithic-black and red ware complex in Sri Lanka," Ancient Ceylon, vol. 5, pp. 237-307. 1984.

[11] R. Somadeva, Urban Origins in Southern Sri Lanka, Uppsala: Uppsala University, 2006.

[12] S. Bandaranayake, "Ancient cities and settlements," The National Atlas of SriLanka, Colombo; Survey Department, 1988.

[13] M. C. Chisholm, "Rural settlement and use," An Assay in Location, Chicago-Aldine, 1968.

[14] B. G. Trigger, History and Settlements in Lower Nubia, New Haven Yale University press, 1965.

[15] S. Senevirathne, "'Peripheral regions' and 'marginal communities': Towards an alternative explanation of early Iron Age material and social formations in Sri Lanka." Tradition, Descent and Ideology: Essays in Honor of Romilar Thapar, Delhi: OUP. 1996.

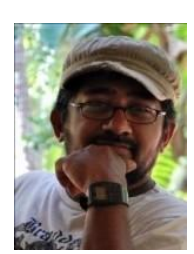

Mangala Katugampola was born in Colombo, Sri Lanka in 1972. He received his bachelor degree in archaeology University of Kelaniya in 1998. He got his M.Phil degree in GIS and settlement archaeology at Postgraduate Institute of Archaeology, University of Kelaniya Sri Lanka. He obtained his doctoral degree in GIS and Settlement archaeology at Sichuan University, China 2015. He concentrates his studies on GIS and Archaeology and visual media in Archaeology. At the moment he has been working as senior lecturer at Kelaniya University, Sri Lanka. 